\title{
Soil microbial diversity in organic and non-organic pasture systems
}

\author{
Mohan Acharya ${ }^{\text {Corresp., } 1}$, Amanda J Ashworth ${ }^{2}$, Yichao Yang ${ }^{3}$, Joan M Burke ${ }^{4}$, Jung Ae Lee ${ }^{5}$, Roshani Sharma \\ Acharya ${ }^{6}$ \\ ${ }^{1}$ Department of Animal Science, University of Arkansas at Fayetteville, Fayetteville, Arkansas, United States of America \\ 2 Poultry Production and Product Safety Research Unit, United States Department of Agriculture, Agricultural Research Service, Fayetteville, Arkansas, \\ United States of America \\ 3 Department of Crop, Soil, and Environmental Science, University of Arkansas at Fayetteville, Fayetteville, Arkansas, United States of America \\ 4 United States Department of Agriculture, Agriculture Research Service, Dale Bumpers Small Farms Research Center, Booneville, Arkansas, United States \\ of America \\ 5 Agriculture Statistics Lab, University of Arkansas at Fayetteville, Fayetteville, Arkansas, United States of America \\ 6 Entomology and Plant Pathology, University of Arkansas at Fayetteville, Fayetteville, Arkansas, United States of America \\ Corresponding Author: Mohan Acharya \\ Email address: macharya@uark.edu
}

Understanding the effects of organic pasture management on the soil microbiome is important for sustainable forage production since soil microbiome diversity contributes to improved nutrient cycling, soil structure, plant growth, and environmental resiliency; however, the soil microbiome response to pasture management is largely unknown. This study assessed the soil microbial diversity, richness, and community structure following 10 years of pasture management (organic or non-organic) of the V4 region of the 16S rRNA using the Illumina MiSeq platform. Soil samples were collected from 0-15 cm in July and August from 2017-2018 and soil nutrient properties (nutrients, carbon, nitrogen, and pH) quantified and correlated with soil microbial diversity. Overall, greater soil bacterial species richness ( $P \leq 0.05$ ) occurred in organic relative to non-organic (conventional) systems. Management affected bacterial species richness (Chao1), with greater richness occurring in organic pasture soils and less richness occurring in non-organic systems ( $P \leq$ 0.05). Similarly, management affected bacterial evenness (Simpson's index), with a more diverse community occurring in organically managed soils relative to non-organic pastures $(P \leq 0.05)$. Linear discriminant analysis effect size analysis showed statistically significant and biologically consistent differences in bacterial taxa in organic compared with nonorganic soils. Therefore, there was a shift in bacterial community structure in organic relative to non-organic soils ( $\mathrm{P} \leq \mathrm{0.05}$ ). Additionally, soil nutrients ( $\mathrm{Fe}, \mathrm{Mg}, \mathrm{Ni}, \mathrm{S}, \mathrm{Al}, \mathrm{K}, \mathrm{Cd}$, and $\mathrm{Cu}$ ), $\mathrm{pH}, \mathrm{C}$, and $\mathrm{N}$ were correlated with one or more dominant bacterial phyla (Gemmatimonadetes, Planctomycetes, Firmicutes, Chloroflexi, Actinobacteria, and Acidobacteria). Overall, pasture management affected soil microbial diversity, with greater 
diversity occurring in organic than non-organic systems, likely owing to applications of organic poultry litter in organic systems compared to non-organic management (use of inorganic-fertilizers and herbicides). Results indicate that when pastures are converted to organic production systems, soil microbial richness and diversity may increase, thereby resulting in enhanced soil microbiome diversity and overall ecosystem services. 


\section{Soil microbial diversity in organic and non-organic} 2 pasture systems

3

4

5 6 7

6
Mohan Acharya ${ }^{1 *}$, Amanda J. Ashworth ${ }^{2}$, Yichao Yang 3 , Joan M. Burke ${ }^{4}$, Jung Ae Lee ${ }^{5}$, and Roshani Sharma Acharya ${ }^{6}$

${ }^{1}$ Department of Animal Science, University of Arkansas at Fayetteville, Fayetteville, AR, USA ${ }^{2}$ Poultry Production and Product Safety Research Unit, United States Department of Agriculture, Agricultural Research Service, Fayetteville, AR, USA

${ }^{3}$ Department of Crop, Soil, and Environmental Sciences, University of Arkansas at Fayetteville, Fayetteville, AR, USA

${ }^{4}$ Dale Bumpers Small Farms Research Center, United States Department of Agriculture, Agriculture Research Service, Booneville, AR, USA

${ }^{5}$ Agricultural Statistics Laboratory, University of Arkansas at Fayetteville, Fayetteville, AR, USA

${ }^{6}$ Entomology and Plant Pathology, University of Arkansas at Fayetteville, Fayetteville, AR, USA

Corresponding Author:

Mohan Acharya

1120 W. Maple St., AFLS B107, Fayetteville, AR

Email address: macharya@uark.edu

Keywords: Organic and non-organic livestock pasture, soil microbiome, microbial abundance, 16S rRNA gene amplicons

Abbreviations: C, Carbon; N, Nitrogen; Al, Aluminum; As, Arsenic; B, Boron; Ca, Calcium; Cd, Cadmium; Co, Cobalt; Cr, Chromium; $\mathrm{Cu}$, Copper; Fe, Iron; K, Potassium; Mg, Magnesium; Mn, Manganese; Mo, Molybdenum; Na, Sodium; Ni, Nickel; P, Phosphorus; Pb, lead; S, Sulfur; Se, Selenium; Ti, Titanium; and Zn, Zinc; DNA, Deoxyribonucleic acid; rRNA, Ribosomal ribonucleic acid; OUT, Operational taxonomic unit, ANOVA, Analysis of variance; PERMANOVA, Permutational multivariate analysis of variance; PCoA, Principle coordinate analysis; LDA, Linear discriminant analysis; and LEfSe, Linear discriminant analysis effect size 


\section{Abstract}

41 Understanding the effects of organic pasture management on the soil microbiome is important

42 for sustainable forage production since soil microbiome diversity contributes to improved

43 nutrient cycling, soil structure, plant growth, and environmental resiliency; however, the soil

44 microbiome response to pasture management is largely unknown. This study assessed the soil

45 microbial diversity, richness, and community structure following 10 years of pasture

46 management (organic or non-organic) of the V4 region of the 16S rRNA using the Illumina

47 MiSeq platform. Soil samples were collected from 0-15 cm in July and August from 2017-2018

48 and soil nutrient properties (nutrients, carbon, nitrogen, and $\mathrm{pH}$ ) quantified and correlated with

49 soil microbial diversity. Overall, greater soil bacterial species richness $(P \leq 0.05)$ occurred in

50 organic relative to non-organic (conventional) systems. Management affected bacterial species

51 richness (Chao1), with greater richness occurring in organic pasture soils and less richness

52 occurring in non-organic systems $(P \leq 0.05)$. Similarly, management affected bacterial evenness

53 (Simpson's index), with a more diverse community occurring in organically managed soils

54 relative to non-organic pastures $(P \leq 0.05)$. Linear discriminant analysis effect size analysis

55 showed statistically significant and biologically consistent differences in bacterial taxa in organic

56 compared with non-organic soils. Therefore, there was a shift in bacterial community structure in

57 organic relative to non-organic soils $(P \leq 0.05)$. Additionally, soil nutrients ( $\mathrm{Fe}, \mathrm{Mg}, \mathrm{Ni}, \mathrm{S}, \mathrm{Al}$,

$58 \mathrm{~K}, \mathrm{Cd}$, and $\mathrm{Cu}$ ), $\mathrm{pH}, \mathrm{C}$, and $\mathrm{N}$ were correlated with one or more dominant bacterial phyla

59 (Gemmatimonadetes, Planctomycetes, Firmicutes, Chloroflexi, Actinobacteria, and

60 Acidobacteria). Overall, pasture management affected soil microbial diversity, with greater

61 diversity occurring in organic than non-organic systems, likely owing to applications of organic

62 poultry litter in organic systems compared to non-organic management (use of inorganic-

63 fertilizers and herbicides). Results indicate that when pastures are converted to organic

64 production systems, soil microbial richness and diversity may increase, thereby resulting in

65 enhanced soil microbiome diversity and overall ecosystem services.

66

67

68

69

70

71

72

73

74

75

76

77

Peer) reviewing PDF | (2020:10:53784:1:1:NEW 20 Feb 2021) 


\section{Introduction}

79

80

81

82

83

84

85

86

87

88

89

90

91

92

93

94

95

96

97

98

99

100

101

102

103

104

105

106

107

108

109

110

111

112

113

114

115

116

117

Soils contain highly diverse microorganisms, with $10^{9}$ to $10^{10}$ microorganisms per gram (Gans et al., 2005). Soil bacterial species and diversity are important as they are major decomposers of soil organic matter and can influence carbon and nitrogen turnover rates (Hättenschwiler et al., 2005), which provides substrates to microbes and nutrients to plants. Nitrogen mineralization in the soil also depends on the abundance and diversity of bacterial taxa (De Ruiter et al., 1993). Higher bacterial diversity is crucial for the breakdown of organic matter that involves complex processes such as chitin degradation (Beier \& Bertilsson, 2013). Human activity in soils, including increased use of chemical fertilizers, pesticides, and tillage, has led to a decrease in global soil biodiversity (Hirsch, 2010). Other negative anthropogenic environmental impacts include soil degradation, pesticide accumulation, reduced water availability, and increased greenhouse gas emission, collectively hampering biodiversity (Foley et al., 2005). Conventional farming systems, crop monocultures, use of chemical fertilizers, and intensive use of agrochemicals eliminate certain group of microbes and decrease overall soil microbial diversity (Stagnari et al., 2014).

Organic production practices reduce the use of chemical fertilizers and pesticides and increase sustainable production practices (Gomiero et al., 2011). Organic soil amendments such as manure, may increase soil microbial diversity, richness, and community structure (Chaudhry et al., 2012; Lupatini et al., 2017). However, there are still incomplete understandings of the effects of organic production practices on soil biodiversity (Wu \& Sardo, 2010; Tscharntke et al., 2012; Bünemann et al., 2006). Although, DNA sequencing technologies have made it possible to identify soil bacterial abundance and diversity (Soliman et al., 2017).

Over one-quarter of the Earth's total land area is used for livestock grazing (Herrero et al., 2013). Grazing directly or indirectly impacts soil microbial communities and $\mathrm{C}$ and $\mathrm{N}$ availability because livestock feeds on aboveground plants and returns half of the grazed forage to the soil as feces, changes plant composition, and shifts rhizosphere exudation (Lovell et al., 1995; Manzano \& Návar, 2000; Le Roux et al., 2008; Yang et al., 2013; Tardy et al., 2015). Animal manures in pasture increase soil enzyme activity, nutrient availability, provides food sources for soil microbes, and increases soil bacterial diversity (Ashworth et al., 2017; Das et al., 2017). In a recent study by Yang et al. (2019) found that animal inputs (poultry litter and cattle manure) increased soil microbial diversity and richness by altering the soil nutrient status. Earlier studies also demonstrated grazing pressure impacts soil microbial communities, with positive associations occurring for soil productivity and microbial $\alpha$-diversity, and the suppression of bacterial communities in overgrazed soils (Xun et al., 2018).

Pasture soils are less managed than row crops and thus have greater potential microbial stability (Lauber et al., 2013; Ashworth et al., 2017). Limited studies are available on the impact of organic pasture management on soil microbial communities. Therefore, the objective is to determine how 10 years of livestock pasture management (organic or conventional) impacts soil microbial diversity.

Peer) reviewing PDF | (2020:10:53784:1:1:NEW 20 Feb 2021) 


\section{Materials and methods}

119

120

121

122

123

124

125

126

127

128

129

130

131

132

133

134

135

136

137

138

139

140

141

142

143

144

145

146

147

148

149

150

151

152

153

154

155

156

157

\section{Study management history}

The research was conducted at the USDA-ARS Dale Bumpers Small Farms Research Center in Booneville, Arkansas $\left(35.08^{\circ} \mathrm{N}, 93.98^{\circ} \mathrm{W}\right)$, where plots with different management, i.e., organic and non-organic, were established and consistently managed since 2007 . Thirtytwo-hectare plots utilized for sheep were managed organically since 2007 and certified organic in 2012 (Nature's International Certification Services, Viroqua, WI). Forage type was predominantly tall fescue (Festuca arundinacea). Non-organic sheep pastures were utilized by sheep for more than 30 years and were predominantly bermudagrass (Cynodon dactylon). Both forage types have limitations for sheep production and provide little pollinator habitat. Before plots were established, sheep grazed at approximately $\sim 10$ sheep ha-1 according to forage availability, which was seasonal and dependent on forage species present (Eremopyrum triticeum, Lolium perenne and other voluntary forbs and grasses). Details regarding the soil types of the study area are available in earlier publication from the research site (Thomas et al., 2008). The site received $101 \mathrm{~cm}$ rainfall in 2017 and $129 \mathrm{~cm}$ in 2018, with the 30-year (1987-2017) mean annual precipitation of $126 \mathrm{~cm}$ (Fig. 1A). Mean annual temperature in 2017 and 2018 were 19.1 and $14.8^{\circ} \mathrm{C}$, with a winter minimum of $9.5^{\circ} \mathrm{C}$ and summer maximum of $32.3^{\circ} \mathrm{C}$ (Fig. 1B). Additionally, daily rainfall and temperature (NOAA, 2017 and 2018) for 3 days before sample collection is provided in the Table 1.

\section{Pasture plot preparation for non-organic forage plots}

Two 0.16-ha non-organic plots were used for the non-organic treatment in this study. Nonorganic plots were sprayed with Roundup [N-(phosphonomethyl)glycine)] (41\% glyphosate, 4.67 1 ha-1) in June, July, September, and October of 2016 and January of 2017, and with Outrider [N-[[(4,6-dimethoxy-2-pyrimidinyl)amino]carbonyl]-2-(ethylsulfonyl)imidazo[1,2a]pyridine-3-sulfonamide; \{Sulfosulfuron\}] (Monsanto, St. Louis, MO; 0.0961 ha-1) in September 2016 using a Continental Belton cluster nozzle sprayer (Continental Belton McAlester, SR: A44117, Oklahoma city, OK). Non-organic plots were tilled (Maschio Gaspardo North America Inc., SC 300, Des Moines, IA), and rolled using 12’ Big Guy Roller (Grahl Manufacturing, St. Louis, MO) in October 2016. Long-term (15 years) applications of inorganic nitrogen (ammonium nitrate) were applied to pastures at recommended rates (https://www.uaex.edu/publications/PDF/FSA-2153.pdf). The seed-mixes were Buck's Hangout (Hamilton Native outpost, Elk creek, MO; www.hamiltonnativeoutpost.com/14.5 kg ha-1) used in half of each 0.16 ha plot, and other Tallgrass Inexpensive or Tallgrass Exposed Clay subsoil mix (Prairie Moon, Winona, MN; www.prairiemoon.com; $13.44 \mathrm{~kg}$ ha-1 and $26.8 \mathrm{~kg}$ ha-1, respectively according to commercial nursery recommendations) in the other half of each 0.16 ha plot, planted on February 7, 2017, and again same time in 2018 (species percentage per seed mixes are available in the aforementioned websites). 
158

159

160

161

162

163

164

165

166

167

168

169

170

171

172

173

174

175

176

177

178

179

180

181

182

183

184

185

186

187

188

189

190

191

192

193

194

195

196

197

\section{Organic pasture plot preparation}

Plots were controlled burned using forestry drip torch after establishing a firebreak around the plots. A cover crop of oats (Avena sativa) was planted in the winter before spring planting native seed mixes. One, 0.4 ha organic plot was seeded on February 3, 2017, with "Butterfly and Hummingbird" Mix from Hamilton Native outpost (Elk Creek, MO; www.hamiltonnativeoutpost.com/; at $8.5 \mathrm{~kg}$ ha-1; species composition and percentage of each species are available in the above website). The other organic plot was 0.8 ha planted with Tall Grass Inexpensive (Prairie Moon Nursery; $13.4 \mathrm{~kg}$ ha-1). The seed was drilled onto a prepared seed bed using a Brillion planter (Brillion Farm Equipment, Sure Stand Model SSP-8, Brillion, WI) at a $1.25 \mathrm{~cm}$ depth. Soil fertility was adjusted using poultry litter (4.4 Mg ha-1; fresh weight basis) following the University of Arkansas soil test recommendation (https://www.uaex.edu/publications/PDF/FSA-2153.pdf).

\section{Sheep grazing}

Plots were multifunctional for pollinator habitat and sheep forage. Sheep grazed plots if they became weedy (including Chenopodium album and Ambrosia artemisiifolia), or stubble height reached $1 \mathrm{~m}$. Grazing of the conventional plots occurred to remove excess forage and weeds, but not to the detriment of the native plant species. The stocking rate of each plot was different based on visual assessment of forage availability, which included plant height, the density of unwanted, and desired plants.

\section{Soil sample collection}

Soil samples were collected in July and August of 2017 and repeated again in 2018. Soil samples were collected from $0-15 \mathrm{~cm}$, and soil probes were sterilized between plots with $70 \%$ ethanol. Samples were packed in sterile whirl-pack bags and stored at $-20^{\circ} \mathrm{C}$ until analysis.

Soil sample collection sites were georeferenced using a Global Positioning System unit. For the analysis, 32 independent samples were taken $(2$ per pasture system $\times 2$ sub-samples per treatment $\times 2$ replications $\times 2$ sample dates per year $\times 2$ years).

\section{Soil physiochemical analyses}

Soil samples were dried at $70{ }^{\circ} \mathrm{C}$ for $48 \mathrm{~h}$ and then ground with mortar and pestle to pass through a $2 \mathrm{~mm}$ sieve. Mehlich-3 extractable nutrients (i.e., Al, As, B, Ca, Cd, Co, $\mathrm{Cr}, \mathrm{Cu}, \mathrm{Fe}, \mathrm{K}, \mathrm{Mg}$, $\mathrm{Mn}, \mathrm{Mo}, \mathrm{Na}, \mathrm{Ni}, \mathrm{P}, \mathrm{Pb}, \mathrm{S}, \mathrm{Se}, \mathrm{Ti}$, and $\mathrm{Zn}$ ) were determined using 1:10 soil volume: extractant solution volume ratio (Tucker, 1992) and analyzed by inductively coupled argon-plasma spectrometry using a 7300 IPC-OES DV (Perlin-Elmer, Waltham, MA). Total C and N were analyzed via dry combustion using a Vario Max CN combustion analyzer (Elementar Americas Inc., Mt. Laurel, NJ). Soil pH was determined on 1:1 soil: distilled water suspension using a symphony B30PCI probe (VWR International, Atlanta, GA).

\section{DNA extraction, PCR amplification, and sequencing}


198 Most of the methods adopted here are previously described in Gurmessa et al. (2021). Briefly,

199

200

201

202

203

204

205

206

207

208

209

210

211

212

213

214

215

216

217

218

219

220

221

222

223

224

225

226

227

228

229

230

231

232

233

234

235

236

237

DNA was extracted from each soil samples using MpBio Fast DNA Spin kit (MpBio

Laboratories, SKU 116560200-CF) following manufacturer's protocol. DNA thus extracted was quantified using Quant-ItTM PicoGreen ${ }^{\circledR}$ (Invitrogen) dsDNA quantitation assay and stored at $20{ }^{\circ} \mathrm{C}$ until further analysis. Bacterial community composition and diversity was determined through classification of 16S rRNA gene by Illumina MiSeq sequencing platform. The V4 region of prokaryotic $16 \mathrm{~S}$ rRNA genes were amplified with barcoded primers $515 \mathrm{~F}$ and $806 \mathrm{R}$ (Caporaso et al., 2011). Libraries for each samples were pooled and sequenced in parallel, and 291 base-paired end sequence were obtained resulting in total 3,531,936 sequence reads. Raw sequences were processed in Mothur software v.1.40.0, using a Miseq SOP protocol (Kozich et al., 2013). Sequences that did not match the primers were eliminated from demultiplexed sequence reads. Sequence reads were clustered into OTUs (Operational Taxonomic Units) at $97 \%$ similarity threshold. After the quality control pipeline, 2,906,534 sequence reads remained while remaining were deleted.

\section{Data analysis and statistics}

The green genes database was used to classify the OUT at the genus level using the Bayesian method (Cole et al. 2009), after that relative abundance of all OTUs was summed within phylum and analyzed for the relative abundance of OTUs at the phylum level. Subsampled data was used to calculate Chao, Shannon and Inverse Simpson index via Mothur and compared results using ANOVA in the statistical software R 3.5.1 (Team, 2013) and JMP R 12 (Institute, 2015).

Weighted and unweighted UniFrac distance, and Bray-Curtis were used to define bacterial betadiversity. Principal coordinate analysis based on weighted and unweighted UniFrac with permutational analysis of variance (PERMANOVA) as statistical methods were carried out to compare bacterial communities at the phylum OUT level (Clark \& Gorley, 2006; Dhariwal et al., 2017). Linear Discriminant Analysis Effect Size measurement was used to identify taxa differences between treatments with Galaxy (Segata et al., 2011).

Spearman correlation was used to find correlation among soil $\mathrm{pH}, \mathrm{C}, \mathrm{N}, \mathrm{C}: \mathrm{N}$ ratio, soil mineral (Al, As, B, Ca, Cd, Co, Cr, Cu, Fe, K, Mg, Mn, Mo, Na, Ni, P, Pb, S, Se, Ti, Zn) and number of OTU of most dominant bacteria phyla per treatment (organic and non-organic system). Management (organic or non-organic) and time of sample collection (July or August) was used as the fixed effect and year and replications as the random effect. Principal component analysis was used to determine relationship among variables using R software. Proportion of variance was done to find variance explained by each PCs. Three PCs that explained most variance were selected for further analysis. The eigenvectors were used to show directional orientation (positive or negative) of all variates with respect to the centroid both in numbers and in figures using PCA biplots.

\section{Results}

Bacterial community composition based on treatment, year, and sampling period

Peer) reviewing PDF | (2020:10:53784:1:1:NEW 20 Feb 2021) 
238 There were differences in soil bacterial communities at the phyla level between sampling years

239

240

241

242

243

244

245

246

247

248

249

250

251

252

253

254

255

256

257

258

259

260

261

262

263

264

265

266

267

268

269

270

271

272

273

274

275

276

277

(2017 and 2018; $P \leq 0.05$ ); however, there were no differences in bacterial communities between non-organic and organic treatments and sampling period [July and August $(P \geq 0.05)$; Table 2]. The following top ten phyla dominated soil bacterial communities: Proteobacteria (mean relative abundance of all libraries was $33.13 \%$ in 2017 vs. $32.63 \%$ in 2018), Bacteriodetes (6.43\% in 2017 vs. $33.44 \%$ in 2018 ), Acidobacteria ( $23.00 \%$ in 2017 vs. $6.86 \%$ in 2018 ), Actinobacteria (8.75\% in 2017 vs. $7.07 \%$ in 2018), Verrucomicrobia (6.78\% in 2017 vs. $8.51 \%$ in 2018 ), Chloroflexi (5.75\% in 2017 vs. 3.64\% in 2018), Firmicutes (5.95\% in 2017 vs. $3.29 \%$ in 2018), Planctomycetes (5.90\% in 2017 vs. $1.74 \%$ in 2018$)$, Gemmatimonadetes ( $3.26 \%$ in 2017 vs. $0.55 \%$ in 2018 ), and Saccharibacteria (1.06\% in 2017 vs. $2.28 \%$ in 2018; Fig. 2A). The top 20 soil bacterial communities at the OTU level are presented in Fig. 2B.

Bacterial community alpha diversity is influenced by treatment, sampling years, and sampling period

Alpha diversity was influenced by treatment (organic vs. non-organic), year, and sampling period, as estimated by three different algorithms (Chao1, Shannon, and Simpson's index). Specifically, management affected bacterial species richness (Chao1), with greater richness found in organic pasture soils and fewer species richness occurring in non-organic soils $(P \leq 0.05)$ (Table 3$)$. Species richness also varied by years, with greater richness occurring in 2017 compared to $2018(P \leq 0.05)$. Richness differences between July and August were at the margin of statistical significance $(P=0.056)$. There were richness differences for treatment $\times$ year $(P \leq 0.05)$. The Simpson's index was used to calculate the evenness of soil bacterial community and indicated treatments affected bacterial evenness, with a more diverse community occurring in organically managed soils, relative to non-organic soils $(P \leq 0.05)$. Year also influenced bacterial community evenness, with greater evenness found in 2018 compared to $2017(P \leq 0.05)$. However, the sampling period did not result in evenness differences $(P \geq 0.05)$. The treatment $\times$ year interaction affected bacterial community evenness $(P \leq 0.05)$. The Shannon index was used to measure the community diversity, including both richness and evenness, and there were no treatment or sampling period differences $(P \geq 0.05)$. The treatment $\times$ year interaction affected bacterial community diversity $(P \leq 0.05)$. Fig. 3A illustrates the influence of treatment and sampling period on soil bacterial richness using Chao1, with Fig. 3B showing bacterial evenness (calculated by using Simpson index), and Fig. 3C presenting the bacterial community diversity (via Shannon index).

\section{Bacterial community structure following treatments and sampling periods}

Community structures across treatments and sampling periods were compared to determine if treatments (non-organic and organic) and sampling periods (July and August) impacted the bacterial community structure. Bray-Curtis distance matrix was used to calculate pairwise distances from all samples. Visualization of these distances using a PCoA revealed an overlap between bacterial communities from treatments and sampling periods. Significant shifts in community structure from non-organic and organic soils were observed in PCoA plots based on

Peer) reviewing PDF | (2020:10:53784:1:1:NEW 20 Feb 2021) 
278 Bray-curtis (PERMANOVA R $=0.183, P \leq 0.05$; Fig. 4). Non-organic samples were distinct

279 from organic samples; however, samples collected from July and August were similar, especially 280 in non-organic systems.

281 The linear discriminant analysis effect size was used to identify bacterial features 282 represented between non-organic and organic soils and between July and August. The log LDA 283 score cutoff was set at 2 (as an absolute value). Both the negative and positive values for the

284

285

286

287

288

289

290

291

292

293

294

295

296

297

298

299

300

301

302

303

304

305

306

307

308

309

310

311

312

313

314

315

316 cutoff can be considered to determine significant features when the score is lower than 2. LEfSe analysis confirmed two features (OTU38 and OTU44), showing statistically significant and biologically consistent differences in non-organic soil samples collected from August. The other two significant features (OTU11 and OTU56) were found in organic soil samples collected in July (Fig. 5). These identified bacterial species reflected distinct abundance in soil samples. LEfSe also detected 11 bacterial species showing statistically significant differences in organic soil samples collected from August. However, no significant feature can be found in samples collected from non-organic soil in July (Fig. 5).

\section{Soil chemical property relationship with bacterial community structure}

The first three PCs were selected (Table 4) for further analysis based on their cumulative variability accounting for $65.80 \%$ of the total variation. Principal component 1 explained $37.42 \%$ of overall variance, while PC2 and PC3 contributed an additional $16.12 \%$ and $12.26 \%$, respectively. Principal component 1 , was most strongly affected by soil N, C, and S contents, which are correlated in Fig. 6, and in the biplot (Fig. 7A,B). All these factors are positive eigenvectors in PC1 which is shown numerically in Table 5, as well as in Fig. 7A and 7B (as all these vectors were directed toward a positive direction with respect to the centroid). Principal component 2 was most strongly associated with soil $\mathrm{pH}, \mathrm{Ca}$, and $\mathrm{P}$ contents. These factors are negative eigenvectors in PC2, which is shown in Table 5, as well as in Fig. 7A and Fig. 7C as these vectors were directed toward the negative side. Likewise, PC3 was closely related to soil $\mathrm{Zn}$ content, Gemmatimonadetes, and Acidobacteria, which are seen in Table 5 and Fig. 7 (B and C).

Soil $\mathrm{pH}$ was negatively correlated with Actinobacteria $(\mathrm{R} 2=-0.61)$, Acidobacteria $(\mathrm{R} 2=$ - 0.50), Chloroflexi $(R 2=-0.45)$, and Planctomycetes $(R 2=-0.48)$. Nitrogen and $C$ were positively correlated with Gemmatimonadetes $(\mathrm{N}, \mathrm{R} 2=0.63 ; \mathrm{C}, \mathrm{R} 2=0.67)$, Planctomycetes $(\mathrm{N}$, $\mathrm{R} 2=0.78 ; \mathrm{C}, \mathrm{R} 2=0.81)$, Firmicutes $(\mathrm{N}, \mathrm{R} 2=0.69 ; \mathrm{C}, \mathrm{R} 2=0.71)$, Chloroflexi $(\mathrm{N}, \mathrm{R} 2=0.45 ; \mathrm{C}$, $\mathrm{R} 2=0.45)$, Actinobacteria $(\mathrm{N}, \mathrm{R} 2=0.60 ; \mathrm{C}, \mathrm{R} 2=0.57)$ and Acidobacteria $(\mathrm{N}, \mathrm{R} 2=0.68 ; \mathrm{C}, \mathrm{R} 2$ $=0.72$ ). The significant correlation between OTUs of dominant bacterial phyla and soil minerals is given in Table 6. Likewise, relationship between soil pH, C, N, C:N ratio, minerals ( $\mathrm{Al}, \mathrm{As}, \mathrm{B}$, $\mathrm{Ca}, \mathrm{Cd}, \mathrm{Co}, \mathrm{Cr}, \mathrm{Cu}, \mathrm{Fe}, \mathrm{K}, \mathrm{Mg}, \mathrm{Mn}, \mathrm{Mo}, \mathrm{Na}, \mathrm{Ni}, \mathrm{P}, \mathrm{Pb}, \mathrm{S}, \mathrm{Se}, \mathrm{Ti}, \mathrm{Zn}$ ) and number of OTU of most dominant bacteria phyla can be seen in Fig. 5 and Fig. 7 A-C.

\section{Discussion}


319

320

321

322

323

324

325

326

327

328

329

330

331

332

333

334

335

336

337

338

339

340

341

342

343

344

345

346

347

348

349

350

351

352

353

354

355

The study was conducted to assess the microbial diversity, richness and community structure using $16 \mathrm{~S}$ rRNA sequencing between soil samples taken from organic and non-organic pasture systems. Long-term organic or non-organic pasture management affected soil microbial diversity, richness, and community structure. Soil bacterial species richness (Chao1) was greater in organic in comparison to non-organic pastures. Likewise, greater bacterial evenness (Simson's index) occurred in organic relative to non-organic pasture, and finally, greater microbial diversity was found in organic than non-organic pastures. Recent publications also suggests that organic management supports greater microbiome assemblages than non-organic systems, (Chen et al., 2020). The greater microbial diversity in organically managed soil in the current study is consistent with other studies (Hartmann et al., 2015; Mäder et al., 2002). Higher diversity of microbial communities in organically managed pastures is likely related to the restricted use of chemical fertilizers and pesticides and with applications of poultry litter, which provides essential macronutrients for microbial growth and function (Sun et al., 2004; Chaudhry et al., 2012; Ashworth et al., 2017; Yang et al., 2019).

Increases in microbial diversity cause a more heterogeneous distribution of bacterial species, leading to healthier plant-soil associations and ecosystems benefits for improved sustainability (Brussaard et al., 2007; Crowder et al., 2010). In non-organic pastures, herbicides and chemical fertilizers are regularly applied, causing long-term stress to microbial populations leading to less diverse microorganisms, in part, because these chemicals potentially inhibit or eliminate certain groups of bacteria and select few bacterial phyla that could thrive in nonorganic management systems (El Fantroussi et al., 1999; Stagnari et al., 2014).

In the current study, organic pastures were grazed by certified organic sheep (Nature's International Certification Services) and non-organic pastures by non-organic sheep. Pastures were regularly soil tested and continuously applied with animal manure (organic pastures) or synthetic fertilizers (in non-organic pastures), thus soil nutrients were never limited. A high nutritent availability could have dominated the presence of copiotrophic bacteria such as Proteobacteria, Firmicutes, Gemmatimonadetes, and Bacteroidetes (Ryckeboer et al., 2003; Fierer et al., 2007, 2012; Zhang et al., 2018), accounting for more than $60 \%$ of the total bacteria phyla. Similarly, other oligotrophic microorganisms, such as actinobacteria and acidobacteria (Fierer et al., 2007) bacterial were also presented but in a relatively lower percentage. All of the bacterial communities were dominated by a few major phyla including: Proteobacteria, Bacteriodetes, Acidobacteria, Actinobacteria, Verrucomicrobia, Chloroflexi, Firmicutes, Planctomycetes, Gemmatimonadetes, and Saccharibacteria. The relative abundance of the most dominant bacterial taxa in this study is similar to that reported by (Davinic et al., 2012; Lupatini et al., 2017). Although, soil samples were taken to compare differences in bacterial taxa between organic and non-organic pastures with different management systems, it is important to

Peer) reviewing PDF | (2020:10:53784:1:1:NEW 20 Feb 2021) 
356

357

358

359

360

361

362

363

364

365

366

367

368

369

370

371

372

373

374

375

376

377

378

379

380

381

382

383

384

385

386

387

388

389

390

391

392

393

394

recognize that most dominant bacteria taxa were largely the same in both treatments and months, with some differences only in their relative abundance.

It is generally thought that grazing affects bacterial species mainly through fecal and urine deposition (Ritz et al., 2004), by altering plant composition (Wang et al., 2001), and shifting rhizosphere exudation (Guitian and Badgett, 2000). Several studies have reported the influence of plant species on soil bacterial communities (Smalla et al., 2001; Schmidt et al., 2019). Also, soil microbial communities are shaped not only by plant species, but also by soil amendment (Schmidt et al., 2019), therefore, this study focused on organic or non-organic soil amendment on livestock pastures.

Relationship between soil $\mathrm{pH}, \mathrm{C}, \mathrm{N}$, soil $\mathrm{C}: \mathrm{N}$ ratio and soil minerals on most dominant bacteria phyla

Although bacteria varied temporally and spatially, overall bacterial diversity was largely predicted by soil $\mathrm{pH}$ (Lauber et al., 2009). The effect of $\mathrm{pH}$ on bacterial community was evident at the phyla level where there was a high relative abundance of Gemmatimonadetes, Planctomycetes, Actinobacteria, Acidobacteria, and Chloroflexi, changing in a consistent manner across the soil $\mathrm{pH}$ gradient as depicted both by Spearman correlation as well as PCA biplots. Though some bacterial taxa are correlated with soil $\mathrm{pH}, \mathrm{pH}$ may not be considered the universal predictor of microbial diversity. The effect of $\mathrm{pH}$ on bacterial community structure and diversity in the current study has been supported by various studies where different sequencing methods were used (Blagodatskaya \& Anderson, 1998; Bååth \& Anderson, 2003; Cookson et al., 2007). Specifically, relative abundance of Acidobateria, Actinobacteria, Planctomycetes, and Chloroflexi were correlated with soil $\mathrm{pH}$, similar to that in the current study (Sait et al., 2006; Eichorst et al., 2007). It is notable that soil $\mathrm{pH}$ and bacterial community structure were correlated; however, it is hard to identify specific mechanisms that cause these relationships. There are two general explanations that may explain why soil $\mathrm{pH}$ was the predictor of bacterial community composition. First, most bacterial taxa have intracellular $\mathrm{pH}$ close to neutral (Madigan \& Martinko, 2005) and are unable to survive if soil $\mathrm{pH}$ falls outside the narrow range of tolerance, i.e., $\mathrm{pH}$ of 6.5-7.5). Lower soil $\mathrm{pH}$ or acidification inhibits bacterial enzyme activity and overall cell mechanics (Beales, 2004), but some microorganisms can survive in acidic environments (Beales, 2004). Second, $\mathrm{pH}$ acts as an integrating factor for several soil variables, e.g., soil organic C, N, P, ion sorption, and salinity, and poultry litter applications are known to increase $\mathrm{pH}$ due to its liming effect (Brady \& Weil, 1999).

Soil microbial communities affect $\mathrm{C}$ and $\mathrm{N}$ turnover with complex interactions involving vegetation types and various soil properties (Bailey et al., 2002; Deng et al., 2016). Therefore, soil microbial community abundance and diversity have significant correlations with soil total $\mathrm{N}$ and C (Liu et al., 2012). In the current study, a strong positive correlation with bacteria phyla (Gemmatimonadetes, Planctomycetes, Firmicutes, Chloroflexi, Actinobacteria, and Acidobacteria) and $\mathrm{N}$ and $\mathrm{C}$ was observed (both Spearman correlation and PCA biplots). This is 
395

396

397

398

399

400

401

402

403

404

405

406

407

408

409

410

411

412

413

414

415

416

417

418

419

420

421

422

423

424

425

426

427

428

429

430

431

432

433

434

important to understand the relationship of soil microbes and for sequestration and stability of $\mathrm{N}$ and $\mathrm{C}$ in grassland soils.

Close contact of soil minerals and soil microorganisms is essential for biogeochemical cycling and transformation of plant nutrients, and by acquiring necessary enzyme cofactors through minerals (Jansson, 1987; Bennett et al., 2001; Semrau et al., 2010; Ahmed \& Holmström, 2014; Jones \& Bennett, 2014). Yet, very limited studies have found a relationship between soil microorganisms and minerals. In the current study, some relationships between dominant soil microbiomes and minerals were observed. Correlations existed between some soil minerals and dominant bacterial taxa. However, other factors such as $\mathrm{pH}$ could have masked the effect, and thus, a future controlled study may be needed to confirm this relationship.

\section{Effect of moisture on soil bacteria}

Precipitation drives bacterial abundance (Clarholm \& Rosswall, 1980); therefore, rainfall data for three days before the sample collection are presented (Table 1). In the current study, Firmicutes and Actinobacteria (both gram-positive bacteria) were able to maintain their relative percentages even in a comparatively drier 2018 compared to 2017. It is because gram-positive cell wall structure allows these microorganisms to withstand dry conditions (Schimel et al., 2007; Lennon et al., 2012; Moreno-Espíndola et al., 2018). Other factors, such as the presence of soil organic $\mathrm{C}$ and bacteria's ability to produce biofilm, also help increase or decrease the abundance of gram-negative bacteria (Malik et al., 2018; Moreno-Espíndola et al., 2018).

Soil microorganisms depend on organic $\mathrm{C}$ for their growth. Plants provide $\mathrm{C}$ to rhizosphere microorganisms in the form of exudates, secretions, lysates, and dead cells (Singh et al., 2004). However, during drought, the quantity and quality of $\mathrm{C}$ available to soil microbes negatively impact gram-negative bacteria as these are more tightly connected to freshly assimilated plant C (Denef et al., 2009). Drastic decreases of Acidobacteria, Planctomycetes, and Gemmanimonadetes in 2018 could be due to their gram-negative bacterial structure, making them vulnerable to dry soil (Denef et al., 2009). However, some gram-negative bacteria increased, which could be due to biofilms. Though gram-negative by structure, Proteobacteria, Chloroflexi, and Saccharibacteria were able to maintain similar percentages during 2018 compared with 2017 , likely due to their ability to produce biofilms, thus helping them to withstand drought (Or et al., 2007).

\section{Conclusions}

The current study was performed to assess soil microbial diversity, richness, and community structure in organic and non-organic livestock pastures using 16S rRNA sequencing. Most of the dominant bacterial taxa were similar in both management systems with some differences in their relative abundance; however, greater soil microbial diversity was observed in organic livestock pastures. More heterogeneous distribution of bacterial species leads to healthier associations at the soil-plant-animal nexus and ultimately improves sustainable agriculture production. Though 
$435 \mathrm{pH}$ was correlated with the most dominant bacterial phyla, soil properties such as $\mathrm{C}$ and $\mathrm{N}$ were 436 more strongly correlated. Additionally, we observed a correlation between several soil minerals 437 ( $\mathrm{Fe}, \mathrm{Mg}, \mathrm{Ni}, \mathrm{S}, \mathrm{Al}, \mathrm{K}, \mathrm{Cd}$, and $\mathrm{Cu}$ ) and bacterial phyla (Gemmatimonadetes, Planctomycetes, 438 Firmicutes, Chloroflexi, Actinobacteria, and Acidobacteria). Limited studies are available that 439 outline the relationship between soil minerals and bacterial phyla. However, soil minerals are 440 essential for enzymatic reactions, biochemical cycling, production of chelating agents, and 441 catalyzing reactions. Overall, greater soil microbial diversity in the organic system, suggests 442 organically produced poultry litter, less herbicide and antibiotic use (during poultry and sheep 443 production) resulted in greater soil microbial diversity than the conventional sheep system. 444 Further studies are needed to ascertain driving soil factors for microbial abundance to optimize 445 soil function in the largest land-use category in the US, or grasslands.

446

447 Acknowledgements

448

449 The authors acknowledge Taylor Cass Adams and Sonia Tsai (USDA-ARS, Fayetteville, AR) 450 Michelle Armstrong and Jenny Richter (USDA-ARS, Booneville, AR) and Lillian Meadors, 451 Jamie Hess (University of Arkansas) for their help during the trial. Mention of trade names or 452 commercial products in this manuscript is solely for providing specific information and does not 453 imply recommendations or endorsement by the U.S. Department of Agriculture. USDA is an 454 equal opportunity provided and employer.

455

456

457

458

459

460

461

462

463

464

465

466

467

468

469

470

471

Peer) reviewing PDF | (2020:10:53784:1:1:NEW 20 Feb 2021) 
472 References

473

474

475

476

477

478

479

480

481

482

483

484

485

486

487

488

489

490

491

492

493

494

495

496

497

498

499

500

501

502

503

504

505

506

507

508

509

510

511

Ahmed E, and Holmström SJ. 2014. Siderophores in environmental research: roles and applications. Microbial biotechnology 7:196-208.

Ashworth A, DeBruyn J, Allen F, Radosevich M, and Owens P. 2017. Microbial community structure is affected by cropping sequences and poultry litter under long-term no-tillage. Soil Biology and Biochemistry 114:210-219.

Bailey VL, Smith JL, and Bolton Jr H. 2002. Fungal-to-bacterial ratios in soils investigated for enhanced C sequestration. Soil Biology and Biochemistry 34:997-1007.

Beales N. 2004. Adaptation of microorganisms to cold temperatures, weak acid preservatives, low $\mathrm{pH}$, and osmotic stress: a review. Comprehensive reviews in food science and food safety 3:1-20.

Beier S, and Bertilsson S. 2013. Bacterial chitin degradation-mechanisms and ecophysiological strategies. Frontiers in microbiology 4:149.

Bennett PC, Rogers J, Choi W, and Hiebert F. 2001. Silicates, silicate weathering, and microbial ecology. Geomicrobiology Journal 18:3-19.

Blagodatskaya EV, and Anderson T-H. 1998. Interactive effects of $\mathrm{pH}$ and substrate quality on the fungal-to-bacterial ratio and $\mathrm{qCO} 2$ of microbial communities in forest soils. Soil Biology and Biochemistry 30:1269-1274.

Brady NC, and Weil RR. 1999. The nature and properties of soil 12th ed. Mac Pub Com New York, 625-640.

Brussaard L, De Ruiter PC, and Brown GG. 2007. Soil biodiversity for agricultural sustainability. Agriculture, ecosystems \& environment 121:233-244.

Bååth E, and Anderson T-H. 2003. Comparison of soil fungal/bacterial ratios in a $\mathrm{pH}$ gradient using physiological and PLFA-based techniques. Soil Biology and Biochemistry 35:955963.

Bünemann EK, Schwenke G, and Van Zwieten L. 2006. Impact of agricultural inputs on soil organisms - a review. Soil Research 44:379-406.

Caporaso JG, Lauber CL, Walters WA, Berg-Lyons D, Lozupone CA, Turnbaugh PJ, Fierer N, and Knight R. 2011. Global patterns of 16S rRNA diversity at a depth of millions of sequences per sample. Proceedings of the national academy of sciences 108:4516-4522.

Chaudhry V, Rehman A, Mishra A, Chauhan PS, and Nautiyal CS. 2012. Changes in bacterial community structure of agricultural land due to long-term organic and chemical amendments. Microbial ecology 64:450-460.

Chen QL, Ding J, Zhu D, Hu HW, Delgado-Baquerizo M, Ma YB, He JZ, Zhu YG. 2020. Rare microbial taxa as the major drivers of ecosystem multifunctionality in long-term fertilized soils. Soil Biology and Biochemistry 1:141

Clarholm M, and Rosswall T. 1980. Biomass and turnover of bacteria in a forest soil and a peat. Soil Biology and Biochemistry 12:49-57. 
512 Clarke KR, Gorley RN. 2006. PRIMER V6: user manual/tutorial edu. Plymouth: PRIMER-E $513 \quad$ ltd.

514 Cole JR, Wang Q, Cardenas E, Fish J, Chai B, Farris RJ, Kulam-Syed-Mohideen A, 515 McGarrell DM, Marsh T, and Garrity GM. 2009. The Ribosomal Database Project:

516

517 improved alignments and new tools for rRNA analysis. Nucleic acids research 37:D141-

518

519

520

521

522

523

524

525

526

527

528

529

530

531

532

533

534

535

536

537

538

539

540

541

542

543

544

Cookson W, Osman M, Marschner P, Abaye D, Clark I, Murphy D, Stockdale E, and Watson C. 2007. Controls on soil nitrogen cycling and microbial community composition across land use and incubation temperature. Soil Biology and Biochemistry 39:744-756.

Crowder DW, Northfield TD, Strand MR, and Snyder WE. 2010. Organic agriculture promotes evenness and natural pest control. Nature 466:109-112.

Das S, Jeong ST, Das S, and Kim PJ. 2017. Composted cattle manure increases microbial activity and soil fertility more than composted swine manure in a submerged rice paddy. Frontiers in Microbiology 8:1702

Davinic M, Fultz LM, Acosta-Martinez V, Calderón FJ, Cox SB, Dowd SE, Allen VG, Zak JC, Moore-Kucera J. 2012. Pyrosequencing and mid-infrared spectroscopy revel distinct aggregate stratification of soil bacterial communities and organic matter composition. Soil Biology and Biochemistry 46:63-72

De Ruiter P, Van Veen J, Moore J, Brussaard L, and Hunt H. 1993. Calculation of nitrogen mineralization in soil food webs. Plant and Soil 157:263-273.

Denef K, Roobroeck D, Wadu MCM, Lootens P, and Boeckx P. 2009. Microbial community composition and rhizodeposit-carbon assimilation in differently managed temperate grassland soils. Soil Biology and Biochemistry 41:144-153.

Deng Q, Cheng X, Hui D, Zhang Q, Li M, and Zhang Q. 2016. Soil microbial community and its interaction with soil carbon and nitrogen dynamics following afforestation in central China. Science of the Total Environment 541:230-237.

Dhariwal A, Chong J, Habib S, King IL, Agellon LB, and Xia J. 2017. MicrobiomeAnalyst: a web-based tool for comprehensive statistical, visual and meta-analysis of microbiome data. Nucleic acids research 45:W180-W188.

Eichorst SA, Breznak JA, and Schmidt TM. 2007. Isolation and characterization of soil bacteria that define Terriglobus gen. nov., in the phylum Acidobacteria. Appl Environ Microbiol 73:2708-2717.

545 El Fantroussi S, Verschuere L, Verstraete W, and Top EM. 1999. Effect of phenylurea

546

547

548

549

550 herbicides on soil microbial communities estimated by analysis of 16S rRNA gene fingerprints and community-level physiological profiles. Appl Environ Microbiol 65:982988.

Fierer N, Bradford MA, Jackson RB. 2007. Toward an ecological classification of soil bacteria. Ecology 88:1354-1364. 
551

552

553

554

555

556

557

558

559

560

561

562

563

564

565

566

567

568

569

570

571

572

573

574

575

576

577

578

579

580

581

582

583

584

585

586

587

588

589

Fierer N, Lauber CL, Ramirez KS, Zaneveld J, Bradford MA, Knight R. 2012. Comparative metagenomic, phylogenetic and physiological analyses of soil microbial communities across nitrogen gradients. The ISME Journal 6:1007-2017.

Foley JA, DeFries R, Asner GP, Barford C, Bonan G, Carpenter SR, Chapin FS, Coe MT, Daily GC, and Gibbs HK. 2005. Global consequences of land use. science 309:570-574.

Gans J, Wolinsky M, and Dunbar J. 2005. Computational improvements reveal great bacterial diversity and high metal toxicity in soil. Science 309:1387-1390.

Gomiero T, Pimentel D, and Paoletti MG. 2011. Environmental impact of different agricultural management practices: conventional vs. organic agriculture. Critical reviews in plant sciences 30:95-124.

Guitian R, Bardgett RD. 2000. Plant and soil microbial responses to defoliation in temperate semi-natural grassland. Plant Soil 220:271-277.

Gurmessa B, Ashworth AJ, Yang Y, Adhikari K, Savin M, Owens P, Sauer T, Pedretti EF, Cocco, S, and Corti G. 2021. Soil bacterial diversity based on management and topography in a silvopastoral system. Applied soil Ecology 163:103918.

Hartmann M, Frey B, Mayer J, Mäder P, and Widmer F. 2015. Distinct soil microbial diversity under long-term organic and conventional farming. The ISME journal 9:11771194.

Hättenschwiler S, Tiunov AV, and Scheu S. 2005. Biodiversity and litter decomposition in terrestrial ecosystems. Anпu Rev Ecol Evol Syst 36:191-218.

Herrero M, Havlík P, Valin H, Notenbaert A, Rufino MC, Thornton PK, Blümmel M, Weiss F, Grace D, and Obersteiner M. 2013. Biomass use, production, feed efficiencies, and greenhouse gas emissions from global livestock systems. Proceedings of the National Academy of Sciences 110:20888-20893.

Hirsch T. 2010. Global biodiversity outlook 3: UNEP/Earthprint.

Institute S. 2015. Base SAS 9.4 procedures guide: SAS Institute.

Jansson M. 1987. Anaerobic dissolution of iron-phosphorus complexes in sediment due to the activity of nitrate-reducing bacteria. Microbial ecology 14:81-89.

Jones AA, and Bennett PC. 2014. Mineral microniches control the diversity of subsurface microbial populations. Geomicrobiology journal 31:246-261.

Kozich JJ, Westcott SL, Baxter NT, Highlander SK, and Schloss PD. 2013. Development of a dual-index sequencing strategy and curation pipeline for analyzing amplicon sequence data on the MiSeq Illumina sequencing platform. Appl Environ Microbiol 79:5112-5120.

Lauber CL, Hamady M, Knight R, and Fierer N. 2009. Pyrosequencing-based assessment of soil $\mathrm{pH}$ as a predictor of soil bacterial community structure at the continental scale. Appl Environ Microbiol 75:5111-5120.

Le Roux X, Poly F, Currey P, Commeaux C, Hai B, Nicol GW, Prosser JI, Schloter M, Attard E, and Klumpp K. 2008. Effects of aboveground grazing on coupling among nitrifier activity, abundance and community structure. The ISME journal 2:221-232.

Peer] reviewing PDF | (2020:10:53784:1:1:NEW 20 Feb 2021) 
590

591

592

593

594

595

596

597

598

599

600

601

602

603

604

605

606

607

608

609

610

611

612

613

614

615

616

617

618

619

620

621

622

623

624

625

626

627

Lennon JT, Aanderud ZT, Lehmkuhl B, and Schoolmaster Jr DR. 2012. Mapping the niche space of soil microorganisms using taxonomy and traits. Ecology 93:1867-1879.

Liu Y, Wei X, Guo X, Niu D, Zhang J, Gong X, and Jiang Y. 2012. The long-term effects of reforestation on soil microbial biomass carbon in sub-tropic severe red soil degradation areas. Forest ecology and management 285:77-84.

Lovell R, Jarvis S, and Bardgett R. 1995. Soil microbial biomass and activity in long-term grassland: effects of management changes. Soil Biology and Biochemistry 27:969-975.

Lupatini M, Korthals GW, de Hollander M, Janssens TK, and Kuramae EE. 2017. Soil microbiome is more heterogeneous in organic than in conventional farming system. Frontiers in microbiology 7:2064.

Mäder P, Fliessbach A, Dubois D, Gunst L, Fried P, Niggli U. 2002. Soil fertility and biodiversity in organic farming. Science 296: 1694-1697.

Madigan MT, and Martinko J. 2005. Brock Biology of Microorganisms, 11th edn. SciELO Espana.

Malik AA, Puissant J, Buckeridge KM, Goodall T, Jehmlich N, Chowdhury S, Gweon HS, Peyton JM, Mason KE, and van Agtmaal M. 2018. Land use driven change in soil pH affects microbial carbon cycling processes. Nature communications 9:1-10.

Manzano MG, and Návar J. 2000. Processes of desertification by goats overgrazing in the Tamaulipan thornscrub (matorral) in north-eastern Mexico. Journal of Arid Environments 44:1-17.

Moreno-Espíndola IP, Ferrara-Guerrero MJ, Luna-Guido ML, Ramírez-Villanueva DA, León-Lorenzana D, Arit S, Gómez-Acata S, González-Terreros E, Ramírez-Barajas B, and Navarro-Noya YE. 2018. The Bacterial Community Structure and Microbial Activity in a Traditional Organic Milpa Farming System Under Different Soil Moisture Conditions. Frontiers in microbiology 9:2737.

National Oceanic and Atmospheric Administration (NOAA). 2017/2018. Climatography of the United States, annual and seasonal normals of temperature and precipitation 20172018: Booneville, Arkansas. United States Department of Commerce, National Climatic Data Center, Ashville.

Mäder P, Fliessbach A, Dubois D, Gunst L, Fried P, and Niggli U. 2002. Soil fertility and biodiversity in organic farming. Science 296:1694-1697.

Or D, Phutane S, and Dechesne A. 2007. Extracellular polymeric substances affecting porescale hydrologic conditions for bacterial activity in unsaturated soils. Vadose Zone Journal 6:298-305.

Ritz K, McNicol JW, Nunan N, Grayston S, Millard P, Atkinson D, Gollotte A, Habeshaw D, Boag B, Clegg CD, Griffiths BS, Wheatley RE, Glover LA, McCaig AE, Prosser JI. 2004. Spatial structure in soil chemical and microbiological properties in an upland grassland. FEMS Microbiology Ecology 49:191-205.

PeerJ reviewing PDF | (2020:10:53784:1:1:NEW 20 Feb 2021) 
628

629

630

631

632

633

634

635

636

637

638

639

640

641

642

643

644

645

646

647

648

649

650

651

652

653

654

655

656

657

658

659

660

661

662

663

664

665

Ryckeboer JR, Mergaert J, Vaes K, Klammer S, Clercq DD, Coosemans J, Insam H, Swings J. 2003. A survey of bacteria and fungi occurring during composting and selfheating processes. Ann of Microbiology 53:349-410.

Sait M, Davis KE, and Janssen PH. 2006. Effect of $\mathrm{pH}$ on isolation and distribution of members of subdivision 1 of the phylum Acidobacteria occurring in soil. Appl Environ Microbiol 72:1852-1857.

Schimel J, Balser TC, and Wallenstein M. 2007. Microbial stress-response physiology and its implications for ecosystem function. Ecology 88:1386-1394.

Schmidt JE, Kent AD, Brisson VL, Gaudin AC. 2019. Agricultural management and plant selection interactively affect rhizosphere microbial community structure and nitrogen cycling. Microbiome 7:1-18.

Segata N, Izard J, Waldron L, Gevers D, Miropolsky L, Garrett WS, Huttenhower C. 2011. Metagenomic biomarker discovery and explanation. Genome Biology 12:R60

Semrau JD, DiSpirito AA, and Yoon S. 2010. Methanotrophs and copper. FEMS microbiology reviews 34:496-531.

Singh BK, Millard P, Whiteley AS, and Murrell JC. 2004. Unravelling rhizosphere-microbial interactions: opportunities and limitations. Trends in microbiology 12:386-393.

Smalla K, Wieland G, Buchner A, Zock A, Parzy J, Kaiser S, Roskot N, Heuer H, Berg G. 2001. Buck and rhizosphere soil bacterial communities studied by denaturing gradient gel electrophoresis: plant-dependent enrichment and seasonal shifts revealed. Applied and Environmental Microbiology 67:4742-4751.

Soliman T, Yang S-Y, Yamazaki T, and Jenke-Kodama H. 2017. Profiling soil microbial communities with next-generation sequencing: the influence of DNA kit selection and technician technical expertise. PeerJ 5:e4178.

Stagnari F, Perpetuini G, Tofalo R, Campanelli G, Leteo F, Della Vella U, Schirone M, Suzzi G, and Pisante M. 2014. Long-term impact of farm management and crops on soil microorganisms assessed by combined DGGE and PLFA analyses. Frontiers in Microbiology 5:1-8.

Sun H, Deng SP, and Raun WR. 2004. Bacterial community structure and diversity in a century-old manure-treated agroecosystem. Appl Environ Microbiol 70:5868-5874.

Tardy V, Spor A, Mathieu O, Lévèque J, Terrat S, Plassart P, Regnier T, Bardgett RD, van der Putten WH, and Roggero PP. 2015. Shifts in microbial diversity through land use intensity as drivers of carbon mineralization in soil. Soil Biology and Biochemistry 90:204-213.

Team RC. 2013. R: A language and environment for statistical computing.

Thomas AL, Brauer DK, Sauer TJ, Coggeshall MV, and Ellersieck MR. 2008. Cultivar influences early rootstock and scion survival of grafted black walnut. Journal of the American Pomological Society 62:3.

Peer) reviewing PDF | (2020:10:53784:1:1:NEW 20 Feb 2021) 
666

667

668

669

670

671

672

673

674

675

676

677

678

679

680

681

682

683

684

685

686

687

688

689

690

691

692

693

694

695

696

697

698

699
Tscharntke T, Clough Y, Wanger TC, Jackson L, Motzke I, Perfecto I, Vandermeer J, and Whitbread A. 2012. Global food security, biodiversity conservation and the future of agricultural intensification. Biological conservation 151:53-59.

Tucker M. 1992. Determination of phosphorus by Mehlich 3 extraction. Soil and media diagnostic procedures for the southern region of the United States Virginia Agricultural Experiment Station Series Bulletin 374:6-8.

Wang SP, Li YH, Wang YF, Chen zz. 2001. Influence of different stocking rates on plant diversity of Artemisia frigida community in Inner Mongolia steppe. Journal of Integrative Plant Biology 43:89-96

Wu J, and Sardo V. 2010. Sustainable versus organic agriculture. Sociology, organic farming, climate change and soil science: Springer, 41-76.

Xun W, Yan R, Ren Y, Jin D, Xiong W, Zhang G, Cui Z, Xin X, and Zhang R. 2018. Grazing-induced microbiome alterations drive soil organic carbon turnover and productivity in meadow steppe. Microbiome 6:170.

Yang Y, Ashworth AJ, DeBruyn JM, Willett C, Durso LM, Cook K, Moore Jr PA, and Owens PR. 2019. Soil bacterial biodiversity is driven by long-term pasture management, poultry litter, and cattle manure inputs. PeerJ 7:e7839.

Yang Y, Wu L, Lin Q, Yuan M, Xu D, Yu H, Hu Y, Duan J, Li X, and He Z. 2013.

Responses of the functional structure of soil microbial community to livestock grazing in the T ibetan alpine grassland. Global change biology 19:637-648.

Zhang Y, Shen H, He X, Thomas BW, Lupwayi NZ, Hao X, Thomas MC, Shi X. 2017. Fertilization shapes bacterial community structure by alteration of soil pH. Frontiers in Microbiology 8:1325. 


\section{Table $\mathbf{1}$ (on next page)}

Daily rainfall and temperature for 3 days before the sample collection in 2017 and 2018 in Booneville, AR. 
1

\begin{tabular}{|c|c|c|c|c|c|c|c|c|c|c|c|c|}
\hline & \multicolumn{6}{|c|}{2017} & \multicolumn{6}{|c|}{2018} \\
\hline & \multicolumn{3}{|c|}{ July } & \multicolumn{3}{|c|}{ August } & \multicolumn{3}{|c|}{ July } & \multicolumn{3}{|c|}{ August } \\
\hline & $2 d^{*}$ & $1 \mathrm{~d}$ & $0 \mathrm{~d}$ & $2 d$ & $1 \mathrm{~d}$ & $0 \mathrm{~d}$ & $2 \mathrm{~d}$ & $1 \mathrm{~d}$ & $0 \mathrm{~d}$ & $2 \mathrm{~d}$ & $1 \mathrm{~d}$ & $0 \mathrm{~d}$ \\
\hline Temperature $\left({ }^{\circ} \mathrm{C}\right)$ & 29.7 & 34.3 & 35.5 & 23.7 & 31.2 & 34.4 & 35.9 & 32.1 & 37.0 & 32.6 & 34.2 & 34.9 \\
\hline Rainfall (mm) & 14.2 & 0.0 & 0.0 & 5.2 & 0.0 & 0.0 & 0.0 & 3.6 & 0.0 & 0.0 & 0.0 & 0.0 \\
\hline
\end{tabular}

2

$3 * \mathrm{~d}=$ number of days before sample collection.

4 


\section{Table 2 (on next page)}

PERMANOVA of bacterial community structure by treatment (organic and non-organic soil), year (2017 and 2018), and sampling period (July and August).

PERMANOVA results illustrate differences in bacterial community structure by single factors of management (organic and non-organic), sample collection years (2017 and 2018), and sampling period (July and August), as well as two factors (treatment $x$ year, treatment $x$ sampling period, and year $\mathrm{x}$ sampling period), and three factors (treatment $\mathrm{x}$ year $\mathrm{x}$ sampling period). 
1

\begin{tabular}{lll}
\hline Factor & Pseudo-F & P-value \\
\hline Treatment & 0.84 & 0.498 \\
Year & 15.26 & $0.001^{*}$ \\
Sampling Period & 0.84 & 0.491 \\
Treatment x Year & 9.55 & $0.001^{*}$ \\
Treatment x Sampling Period & 1.62 & 0.293 \\
Year x Sampling Period & 1.99 & 0.096 \\
Treatment x Sampling Period x Year & 0.82 & 0.465 \\
\hline
\end{tabular}

2 


\section{Table 3 (on next page)}

ANOVA of richness, evenness, and diversity in bacterial community structure of treatment, year and sampling period.

ANOVA results illustrating richness, evenness and diversity in bacterial community structure by single factor of treatment (non-organic and organic), year (2017 and 2018) and sampling period (July and August), as well as two factors (treatment and year). 
1

\begin{tabular}{llll}
\hline Parameter & Factor & F-value & $P$-value \\
\hline Richness & Treatment & 6.58 & $0.0156^{*}$ \\
& Year & 10.37 & $0.0031^{*}$ \\
& Sampling Period & 3.95 & 0.0561 \\
Evenness & Treatment x Year & 4.52 & $0.0425^{*}$ \\
& Treatment & 4.08 & 0.0525 \\
& Year & 11.39 & $0.0021^{*}$ \\
& Sampling Period & 2.01 & 0.1664 \\
Diversity & Treatment x Year & 8.14 & $0.0081^{*}$ \\
& Treatment & 3.78 & 0.0613 \\
& Year & 13.77 & $0.0008^{*}$ \\
& Sampling Period & 2.01 & 0.1666 \\
& Treatment x Year & 13.33 & $0.0011^{*}$ \\
\hline
\end{tabular}

2

3

4 


\section{Table 4(on next page)}

Standard deviation, proportion of variance and cumulative proportion of each principal component.

Standard deviation is the deviation of principal components. Proportion of variance explained how much variance is explained by each of the principal components with respect of the whole (the sum). 
1

\begin{tabular}{lrrr}
\hline & PC1 & PC2 & PC3 \\
\hline Standard deviation & 3.566 & 2.341 & 2.041 \\
Proportion of variance & 0.374 & 0.161 & 0.122 \\
Cumulative proportion & 0.374 & 0.535 & 0.658 \\
\hline
\end{tabular}

2 


\section{Table 5 (on next page)}

Eigenvectors of principal component $(\mathrm{PC}$ ) representing a linear combination of the original variable for soil bacterial phylum and soil properties collected $0-15 \mathrm{~cm}$ in 2017 and 2018. 
1

\begin{tabular}{|c|c|c|c|}
\hline & PC1 & PC2 & PC3 \\
\hline $\mathrm{pH}$ & -0.173 & -0.300 & 0.015 \\
\hline $\mathrm{N}$ & 0.265 & -0.009 & 0.051 \\
\hline C & 0.267 & -0.066 & 0.035 \\
\hline $\mathrm{C}: \mathrm{N}$ ratio & 0.113 & -0.231 & -0.057 \\
\hline $\mathrm{Al}$ & 0.181 & 0.249 & -0.001 \\
\hline As & -0.059 & -0.034 & 0.083 \\
\hline B & 0.179 & 0.105 & 0.264 \\
\hline $\mathrm{Ca}$ & 0.005 & -0.360 & 0.068 \\
\hline $\mathrm{Cd}$ & 0.112 & -0.274 & -0.132 \\
\hline $\mathrm{Co}$ & 0.185 & 0.108 & 0.262 \\
\hline $\mathrm{Cr}$ & -0.133 & -0.147 & -0.200 \\
\hline $\mathrm{Cu}$ & 0.212 & -0.178 & 0.201 \\
\hline $\mathrm{Fe}$ & 0.120 & -0.267 & -0.224 \\
\hline $\mathrm{K}$ & 0.243 & 0.068 & 0.132 \\
\hline $\mathrm{Mg}$ & 0.256 & 0.129 & 0.083 \\
\hline $\mathrm{Mn}$ & 0.024 & -0.180 & -0.031 \\
\hline Mo & 0.026 & 0.029 & 0.212 \\
\hline $\mathrm{Na}$ & 0.057 & 0.080 & 0.131 \\
\hline $\mathrm{Ni}$ & 0.224 & 0.061 & -0.082 \\
\hline $\mathrm{P}$ & 0.109 & -0.349 & 0.051 \\
\hline $\mathrm{Pb}$ & 0.171 & -0.268 & 0.142 \\
\hline $\mathrm{S}$ & 0.266 & -0.026 & -0.006 \\
\hline $\mathrm{Se}$ & 0.161 & -0.062 & 0.078 \\
\hline $\mathrm{Ti}$ & -0.055 & 0.079 & -0.317 \\
\hline $\mathrm{Zn}$ & 0.167 & -0.044 & 0.330 \\
\hline Gemmatimonadetes & 0.202 & -0.047 & -0.264 \\
\hline Planctomycetes & 0.232 & -0.030 & -0.178 \\
\hline Firmicutes & 0.205 & -0.079 & -0.142 \\
\hline Chloroflexi & 0.167 & 0.099 & -0.218 \\
\hline Verrucomicrobia & -0.034 & -0.022 & 0.132 \\
\hline Actinobacteria & 0.191 & 0.154 & -0.159 \\
\hline Acidobacteria & 0.222 & 0.011 & -0.271 \\
\hline Bacteroidetes & -0.139 & -0.036 & 0.259 \\
\hline Proteobacteria & -0.015 & -0.033 & 0.079 \\
\hline
\end{tabular}

2 
Table 6(on next page)

Pearson correlation between soil bacteria (Gemmatimonadetes, Planctomycetes, Firmicutes, Chloroflexi, Actinobacteria, and Acidobacteria) and soil nutrient concentration ( $\mathrm{Fe}, \mathrm{Mg}, \mathrm{Ni}, \mathrm{S}, \mathrm{Al}, \mathrm{K}, \mathrm{Cd}, \mathrm{Cu}$ ) collected 2017 and 2018 to a 0-15 cm depth. 
1

\begin{tabular}{lllllll}
\hline Bacterial phyla & \multicolumn{5}{c}{ Soil minerals } \\
\hline Gemmatimonadetes & $\mathrm{Fe}, \mathrm{R}^{2}=0.66$ & $\mathrm{Mg}, \mathrm{R}^{2}=0.51$ & $\mathrm{Ni}, \mathrm{R}^{2}=0.58$ & $\mathrm{~S}, \mathrm{R}^{2}=0.72$ & & \\
Planctomycetes & $\mathrm{Al}, \mathrm{R}^{2}=0.51$ & $\mathrm{Fe}, \mathrm{R}^{2}=0.60$ & $\mathrm{~K}, \mathrm{R}^{2}=0.52$ & $\mathrm{Mg}, \mathrm{R}^{2}=0.65$ & $\mathrm{Ni}, \mathrm{R}^{2}=0.65$ & $\mathrm{~S}, \mathrm{R}^{2}=0.81$ \\
Firmicutes & $\mathrm{Cd}, \mathrm{R}^{2}=0.51$ & $\mathrm{Cu}, \mathrm{R}^{2}=0.56$ & $\mathrm{~K}, \mathrm{R}^{2}=0.53$ & $\mathrm{Mg}, \mathrm{R}^{2}=0.56$ & $\mathrm{~S}, \mathrm{R}^{2}=0.73$ & \\
Chloroflexi & $\mathrm{K}, \mathrm{R}^{2}=0.53$ & $\mathrm{Mg}, \mathrm{R}^{2}=0.54$ & & & & \\
Actinobacteria & $\mathrm{Al}, \mathrm{R}^{2}=0.56$ & $\mathrm{~K}, \mathrm{R}^{2}=0.58$ & $\mathrm{Mg}, \mathrm{R}^{2}=0.67$ & $\mathrm{~S}, \mathrm{R}^{2}=0.58$ & & \\
Acidobacteria & $\mathrm{Al}, \mathrm{R}^{2}=0.52$ & $\mathrm{Fe}, \mathrm{R}^{2}=0.56$ & $\mathrm{~K}, \mathrm{R}^{2}=0.52$ & $\mathrm{Mg}, \mathrm{R}^{2}=0.63$ & $\mathrm{Ni}, \mathrm{R}^{2}=0.66$ & $\mathrm{~S}, \mathrm{R}^{2}=0.75$ \\
\hline
\end{tabular}

2 
Figure 1

Temperature and rainfall data from study site.

Figure 1. (A) Total monthly precipitation and (B) mean monthly temperature in Booneville, AR in 2017 and 2018. Total monthly precipitation and temperature (1987-2017; 30 Year average) were obtained from NOAA (2018). 

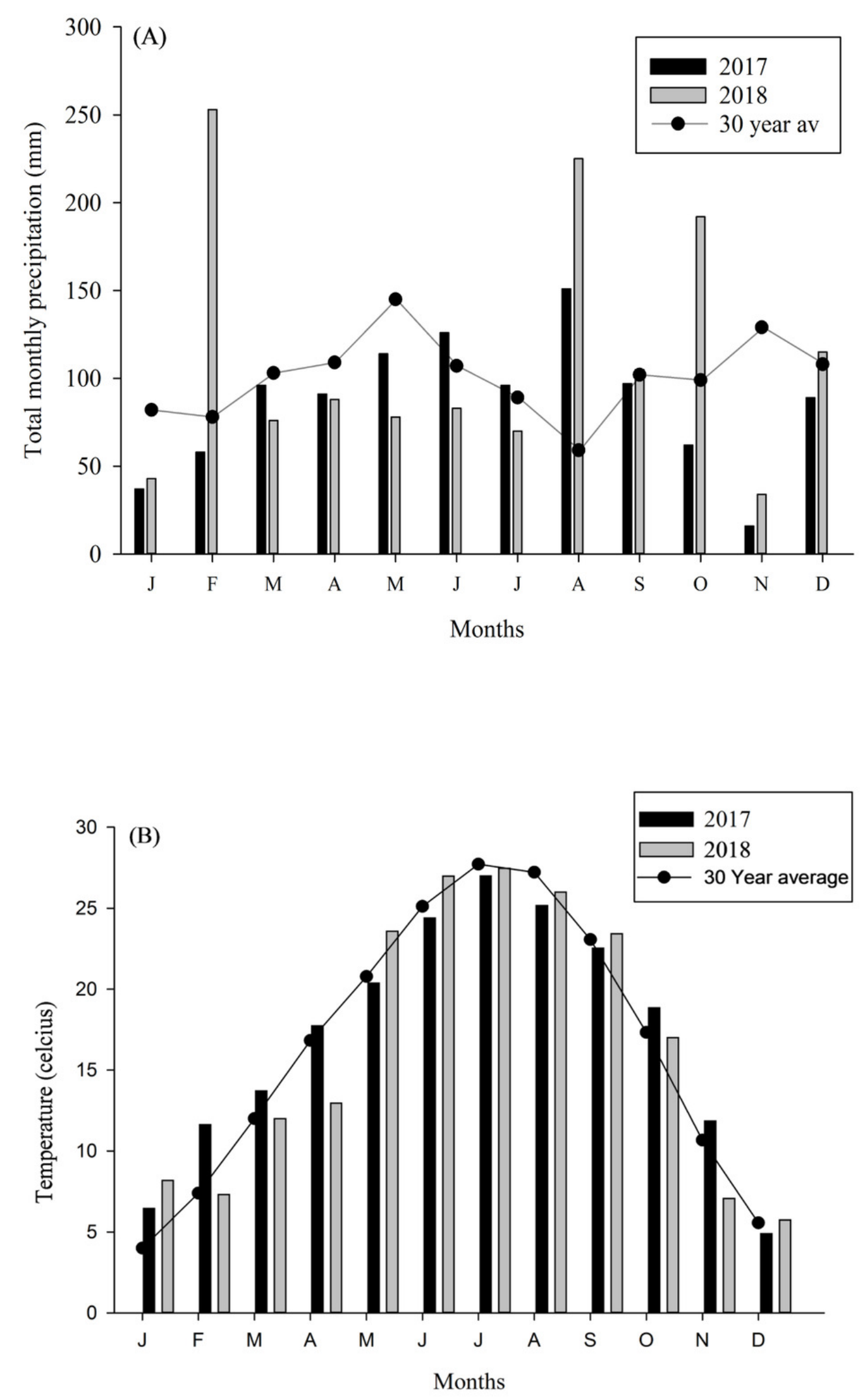


\section{Figure 2}

Proportion of soil bacteria in phylum and OTU level by different pasture management system and sampling period.

Mean relative proportion of soil bacteria in phylum level (A) and in OTU level (B) by treatment and sampling period from 2017-2018. Treatments include non-organic (Non-Org) soil and organic (Org) soil. The sampling period includes July and August (Aug). The order of colors is the same in the legend as the bars. 


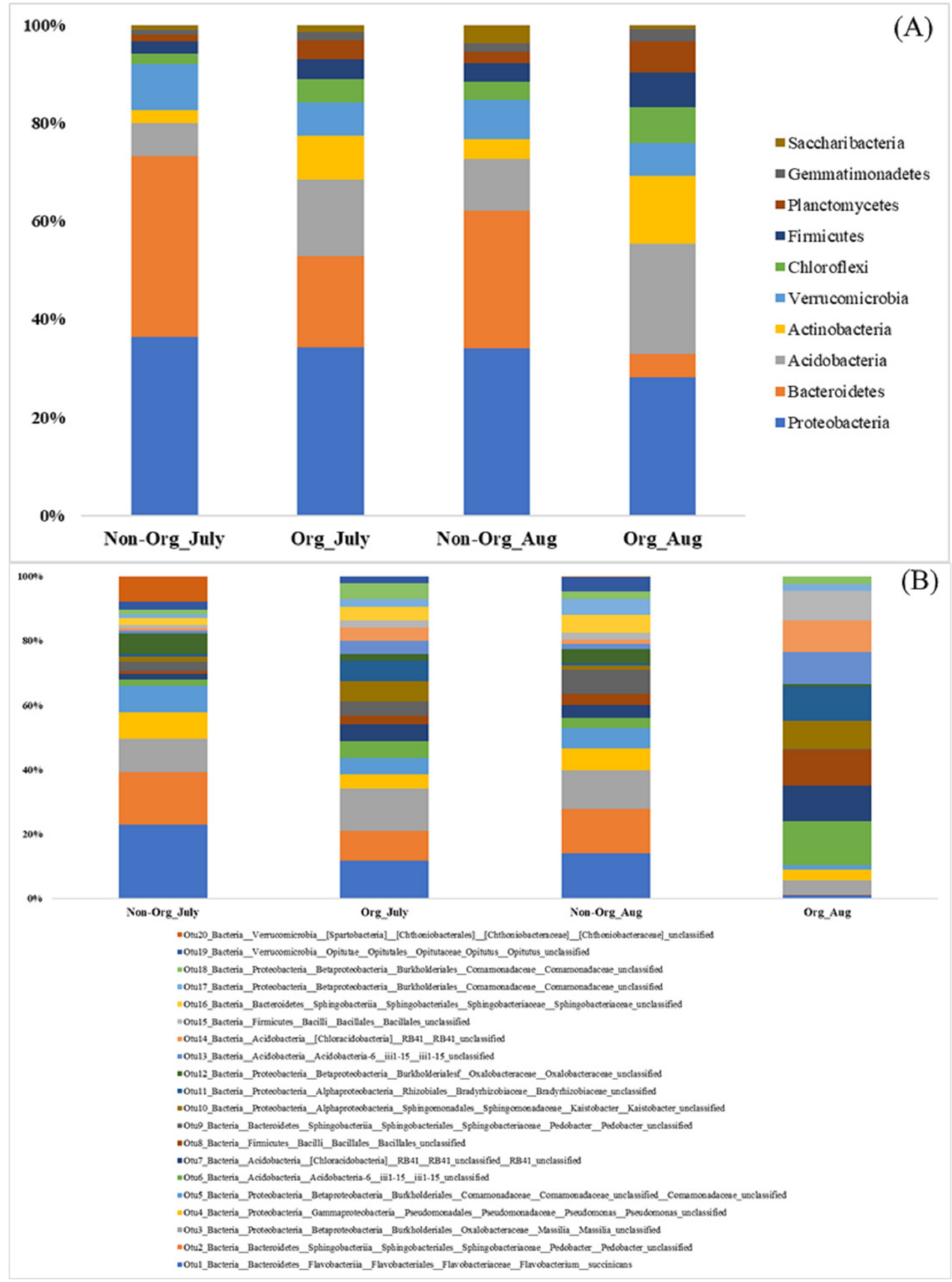


Figure 3

Bacterial richness, evenness, and diversity in different pasture management system.

Mean soil bacterial richness, evenness, and diversity [Chaol (A), Simpson index (B), and Shannon index $(C)$ ] in non-organic and organic pasture management system. Treatments include non-organic (Non-org) and organic (Org) soils. Soil samples were collected during two sampling periods (July and August).
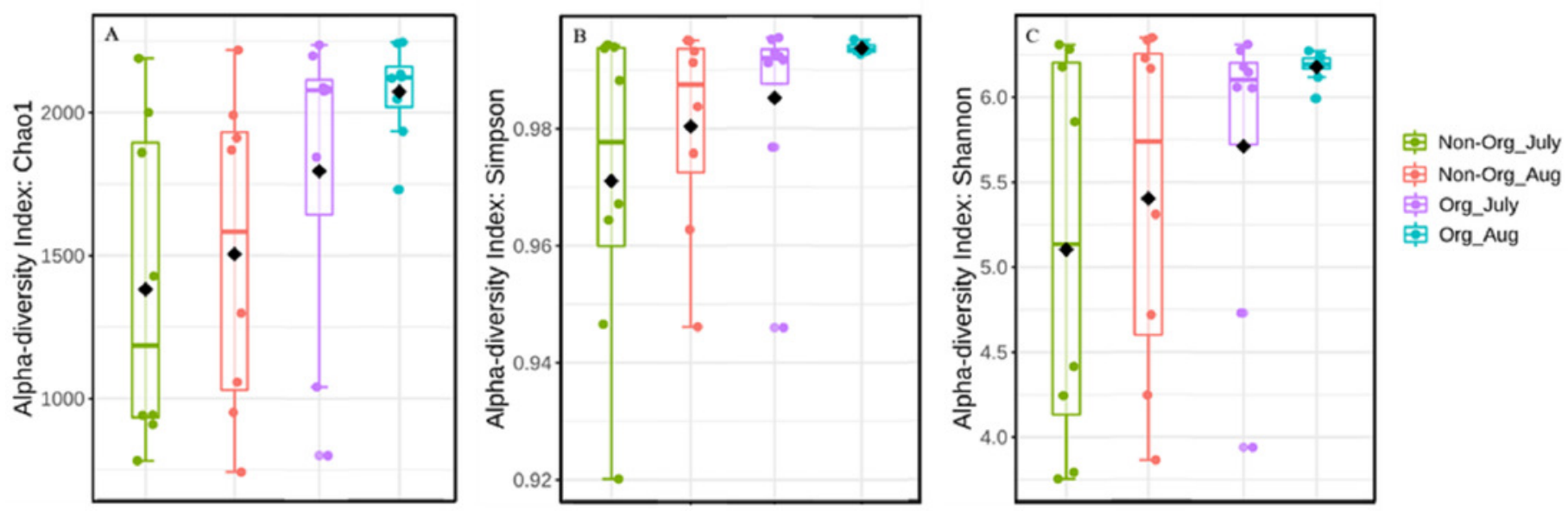


\section{Figure 4}

Principal Coordinated Analysis (PCoA) of Bray-Curtis distances of bacterial community structures in different pasture management system and sampling period.

Principal Coordinated Analysis (PCoA) of Bray-Curtis distances of bacterial community structures in different pasture management. The factors include non-organic (Non-Org) soil and organic (Org) soil collected during two different sampling periods (July and August).

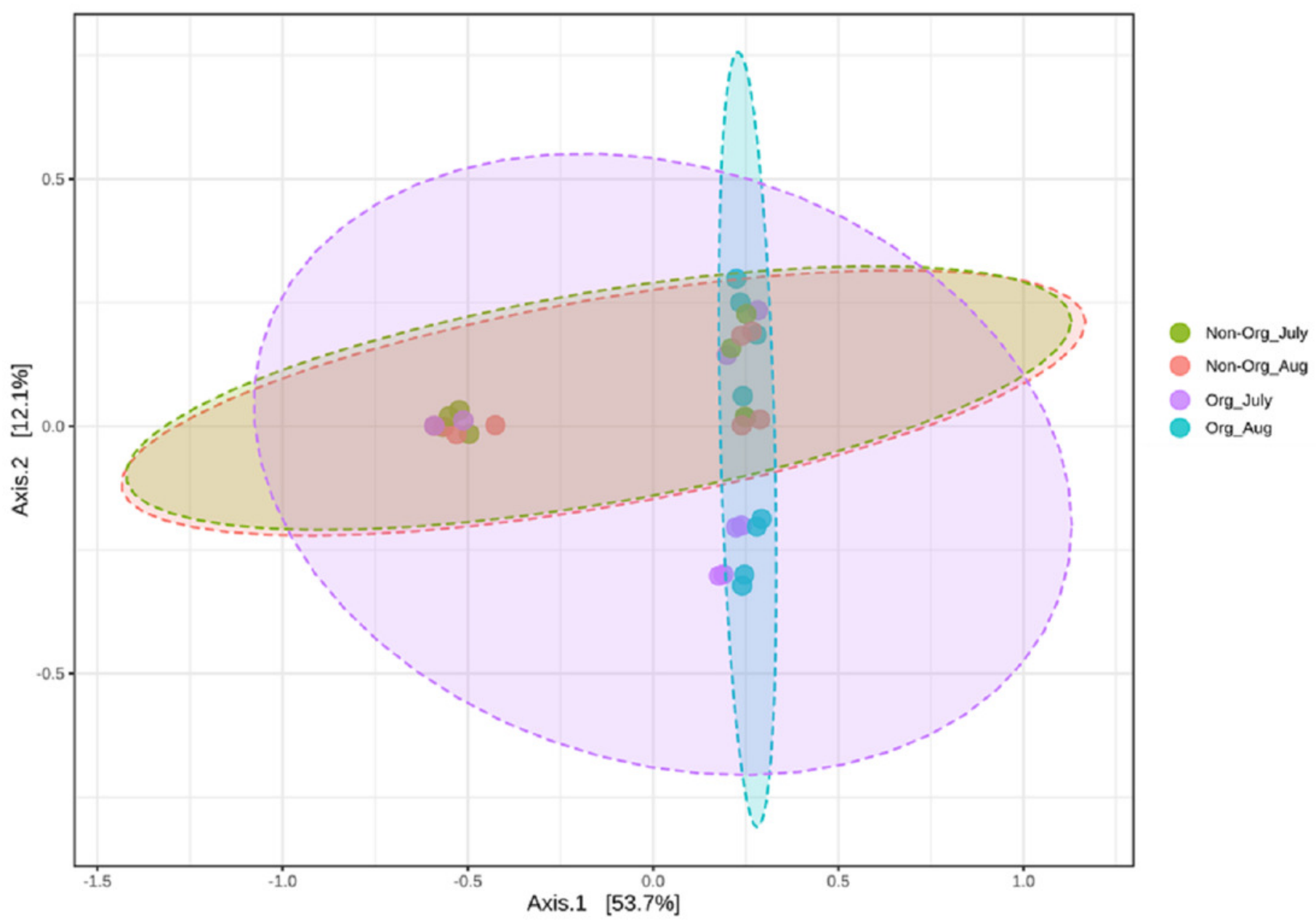




\section{Figure 5}

Linear Discriminant Analysis Effect Size (LefSe) analysis showing OTU abundance for different pasture management system and time period.

Linear Discriminant Analysis Effect Size (LefSe) analysis showing OTU abundance for different groups in non-organic soils collected from August and organic soils collected from July and August. No significant feature was observed in samples collected from non-organic soils in July. 


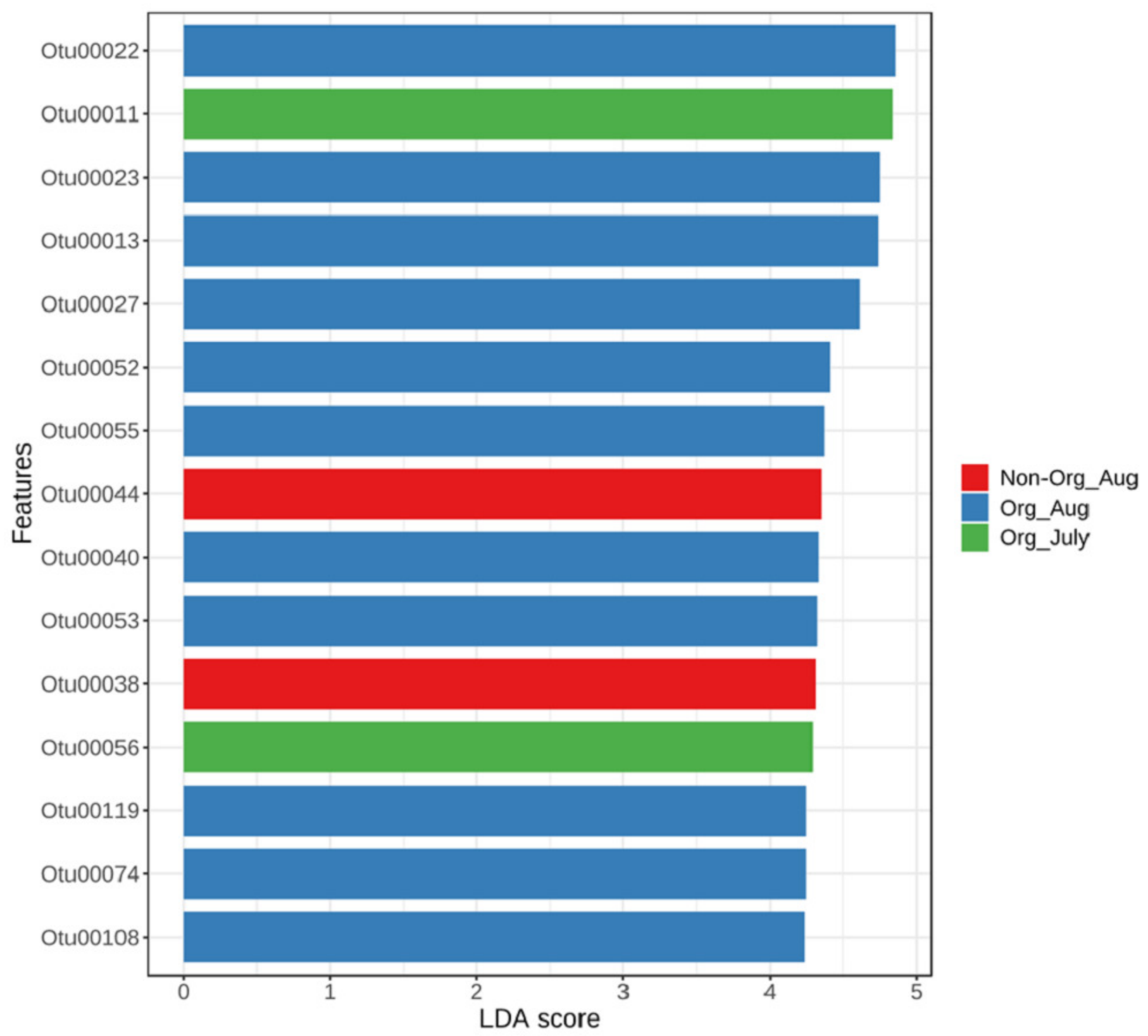


Figure 6

Spearman correlation coefficient of soil variables ( $\mathrm{pH}, \mathrm{N}, \mathrm{C}$ and minerals) and number of operational taxonomic unit (OTU) of major bacteria phyla.

Blue color represents positive correlation, white color shows no correlation and pink color shows negative correlation.

\section{Spearman Correlation coefficients}

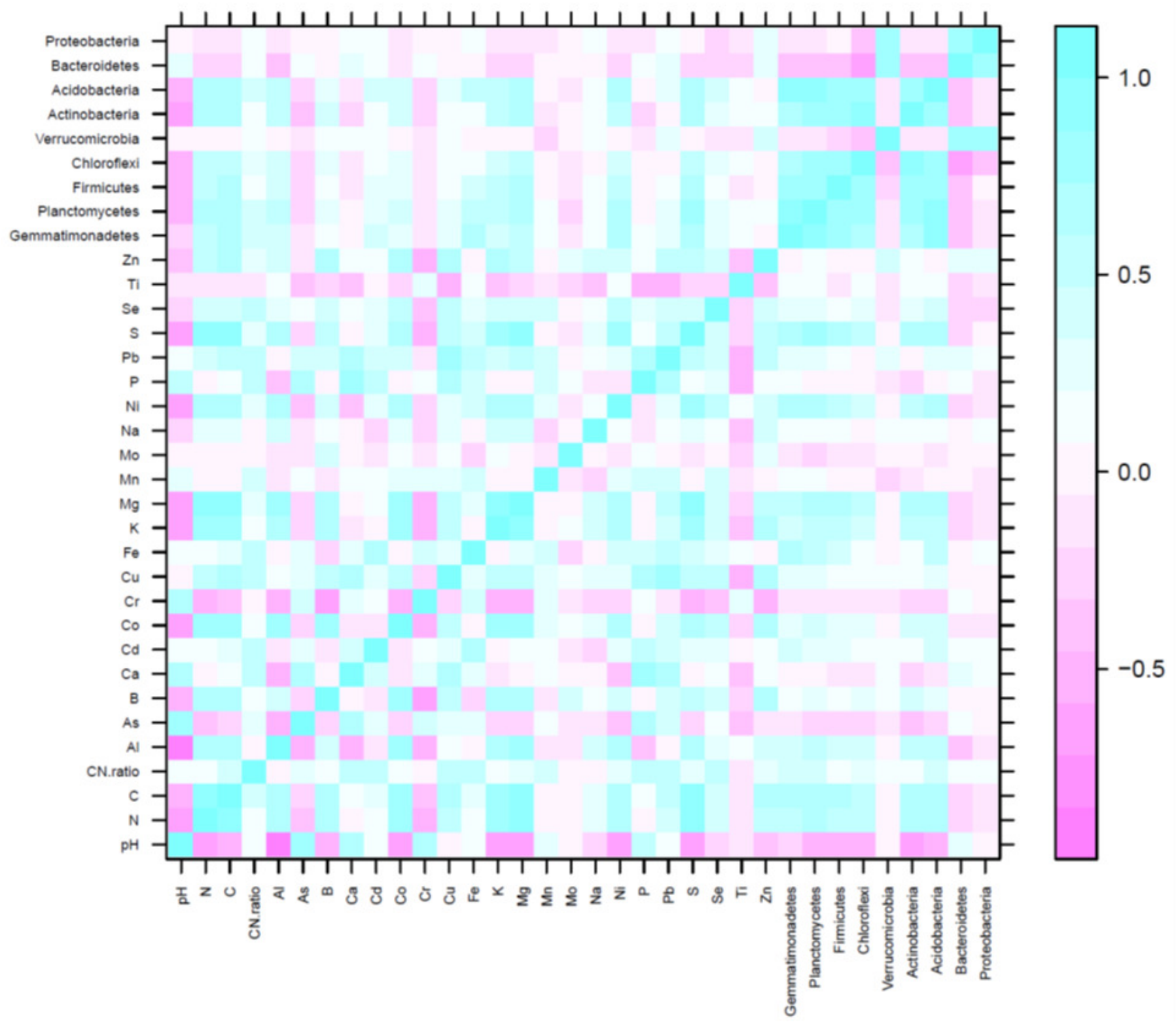


Figure 7

Biplot of soil components ( $\mathrm{pH}, \mathrm{C}, \mathrm{N} \mathrm{C}: \mathrm{N}$ and minerals) and bacteria phyla.

In figure $\mathrm{A}$, the horizontal axis shows the projection on to the principal component 1 (PC1) and the vertical axis of PC2. In figure B and C, vertical axis shows projection on to PC3 while horizontal axis shows projection on to the PC3 and PC2 respectively.
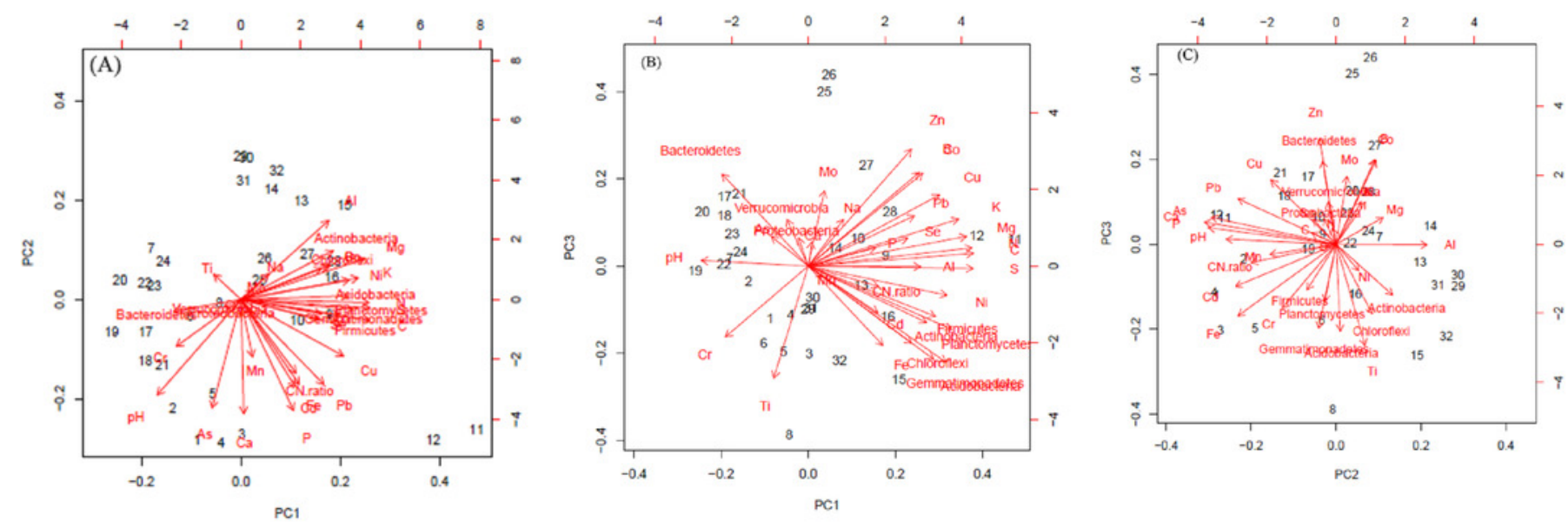